\title{
Antifungal Activity of Bacteria Associated Aplysina sp. Sponge Collected from Enggano Island, North Bengkulu, Indonesia Against Candida albicans
}

\author{
Risky Hadi Wibowo ${ }^{1 *}$, Sipriyadi ${ }^{1}$, Welly Darwis ${ }^{1}$, Sal Prima Yudha ${ }^{2}$, Hizkia Puspa \\ Pertiwi $^{3}$, Reza Pertiwi ${ }^{4}$ \\ ${ }^{1}$ Department of Biology, Faculty of Mathematics and Natural Sciences, Universitas Bengkulu, \\ Kandang Limun, Bengkulu 38112, Indonesia \\ ${ }^{2}$ Department of Chemistry, Faculty of Mathematics and Natural Sciences, Universitas Bengkulu, \\ Kandang Limun, Bengkulu 38112, Indonesia \\ ${ }^{3}$ Undergraduate Student, Department of Biology, Faculty of Mathematics and Natural Sciences, \\ Universitas Bengkulu, Kandang Limun, Bengkulu 38112, Indonesia \\ ${ }^{4}$ Department of Pharmacy, Faculty of Mathematics and Natural Sciences, Universitas Bengkulu, \\ Kandang Limun, Bengkulu 38112, Indonesia. \\ *Corresponding author E-mail: riskyhadiwibowo80@gmail.com
}

\begin{abstract}
Sponges are the subject of interesting antibiotic development studies because the sponges form associations with various microbes and are rich in bioactive compounds. Bacteria associated with sponges are able to produce bioactive compounds, which have the potential to be antimicrobial such as, antibacterial, antifungal and antiviral. Antifungal compounds are bioactive compounds that have the ability to inhibit the growth of pathogenic fungi of Candida albicans. This fungal is an opportunistic pathogen fungi that can cause candidiasis. This study aimed to examine the antifungal activity of bacteria associated Aplysina sp. sponge from Enggano Island, North Bengkulu, Indonesia against Candida albicans. Antagonistic tests were carried out in three stages, by using isolates, pellets and supernatants respectively. The antagonistic assay results showed that four isolates were able to inhibit the growth of the fungus Candida albicans in Vitro, i.e APD3, APD10, APD11 and APD15. The highest inhibitory activity was resulted by APD10 isolate with a clear zone area of $14.9 \mathrm{~mm}$ in culture, $14,0 \mathrm{~mm}$ in pellets and $15.1 \mathrm{~mm}$ in supernatants. The morphological, Gram staining and biochemical characterization showed that the four isolates had a close relationship with the genus of Bacillus.
\end{abstract}

Keywords: Antifungal, Candida albicans, Aplysina sp., Enggano island, Sponges

\section{INTRODUCTION}

Infectious diseases caused by fungi are commonly found in Indonesia, one of which is candidiasis. Candidiasis is caused by the fungus Candida albicans or Candida sp. which can attack various parts or tissues of the body such as the skin, mucous membranes, mouth, digestive tract, respiratory tract, vagina, and nails and cause acute or subacute infections [1].

One of the preventions of candidiasis by giving antifungal. Antifungal are substances that can interfere with the growth and metabolism of fungi. The ideal antifungal material must be to kill fungi (fungicide) and inhibit fungal growth (fungistatic) [2].

The marine ecosystem comprises the richest source of biologically active compounds from marine organisms such as marine animals, including invertebrates, marine plants, and marine microbes. The marine sponges are the filter feeder, sessile organism, and they harbor a rich source of microbes with their body system, and $30 \%$ biomass of the sponge tissue has 1010 microbial load. Based on the microbial abundance, they are categorized into low microbial abundance (LMA 105 -106 ), and the high microbial abundance (HMA 108 -1010) [3].

Marine natural products with a range of biotechnological importance have been isolated from sponges, corals, tunicates, mollusks, algae, bryozoans, and associated microorganisms [4]. Marine invertebrates harbor a higher abundance of symbiotic microorganisms than in seawater environment [5] ; [3]. These symbiotic microorganisms are producers of a diverse range of bioactive compounds especially important for drug discovery. Symbiotic microbial communities also play an important role in the chemical defense of their host sponge against different predators. This strategy of symbiotic microbes plays a key role in the survival of sponge in the marine ecosystem [6]. In recent years, many bioactive secondary metabolites were identified from sponges and 
more than 300 new and novel bioactive compounds were discovered from a single phylum Porifera and subjected to preclinical and clinical trials [7]. The dominant phyla as a producer of bioactive compounds are Actinobacteria, Cyanobacteria, Proteobacteria, Firmicutes and Bacteroidetes in different species of marine sponges i.e Haliclona, Petrosia, Theonella, Dysidea, Xestospongia, Callyspongia, Halichondria, Aplysina, Xestospongia, and Sarcophyton sp. [8].

Microbial communities producing bioactive compounds either live symbiotically or attach transiently with the host. To unravel the interaction of sponge and symbiotic microbial communities, it is important to characterize and identify them from marine sponges. Many previous studies including culture-dependent, and independent techniques were used to identify bacterial communities associated with host sponges, and now more than 39 different phyla have been identified from marine sponges [9]. Several studies have been -performed to isolate and screen bacteria from marine sponges for the production of bioactive metabolites [10].

Porifera (sponge) is one of the primitive animals that live permanently (sedentary) and is a non-selective filter feeder (filtering what is there) [11]. Sea sponges are sessile organisms that play an essential role in coral reef ecosystems and have close associations with various microbes. Microorganisms associated with sponges can reach a density of 109 cells per $\mathrm{cm}^{3}$ what accounts for $35 \%$ of the total biomass of sponge tissue. it has led to a high diversity of bacteria associated with sponges [12] ; [13].

Research on sponges associated with microbes more done and interest for scientists to research it in recently, mostly sponges that produce various active compounds of secondary metabolites. Bioactive compounds from sponges can be used as antibacterial, anti-fungal, anti-tumor, and anticancer properties [12].

Microbes associated with sponges have great potential that it requires efforts to explore further the benefits that can obtain from these sponges, one of which is by selecting the ability of microbes associated with sponges to inhibit the growth of pathogenic fungi. This study was conducted to test the antifungal activity of bacteria isolates associated with sponge Aplysina sp. collected from Enggano Island against Candida albicans. Based on research conducted by [14] that Aplysina sp. has antibacterial and antifungal compounds tested against pathogenic bacteria and yeast.

Enggano Island is one of the outer islands in Indonesia that has a high diversity of marine biota, one of them are sponges. Sponge is a group of multicellular animals, has characteristic porous body, and invertebrate organisms are useful in producing bioactive compounds. Bacteria associated with sponges can be an alternative source of new bioactive compounds, especially antimicrobial [14].

\section{MATERIALS AND METHODS}

\subsection{Materials of Research}

Materials used in this research are Petri dishes, Erlenmeyer flask, beaker glass, measuring cylinder, Bunsen burner, inoculation loop, pipette, micropipette, centrifuge, Laminar Air Flow (LAF), autoclave, sterile filter paper discs, hot plate, Sea Water Complete (SWC), Potato Dextrose Broth (PDB), Potato Dextrose Agar (PDA), Tryptic Soy Agar (TSA), Tryptic Soy Broth (TSB), Candida albicans isolates.

\subsection{Purification of Candida albicans}

The isolated of Candida albicans were subcultured onto sterile PDA and incubated at $37{ }^{\circ} \mathrm{C}$ for $2 \times 24$ hours.

\subsection{Screening of Bacteria for antifungal activity}

$1 \mathrm{ml}$ of microbial liquid culture to be inhibited (24 hours old) was put onto $100 \mathrm{ml}$ of TSA media and poured into a sterile petri dish. Then, bacterial isolates from sponges were spotted on the surface of the media and incubated at $37{ }^{\circ} \mathrm{C}$ for 24 hours. The antifungal compound produced is indicated by the presence of a clear zone around the bacterial colony [15].

The bacterial isolates were cultured in a liquid medium, then $1 \mathrm{ml}$ of culture was centrifuged $(10,000$ rpm, 15 minutes) to separate the pellets and the supernatural. $20 \mu \mathrm{l}$ of pellet and supernatant suspension (separately) dropped on paper discs (allowed to stand for 10-15 minutes). Then, it was put onto the medium and incubated at $37{ }^{\circ} \mathrm{C}$ for 24 hours. The diameter of zone inhibition of antimicrobial compound and activity index calculated by the formula:

DZI = Diameter of zone inhibition - Diameter of colony

$\mathrm{AI}=\underline{\text { Diameter of zone inhibition }- \text { Diameter of colony }}$ Diameter of colony.

\subsection{Identification of Bacterial Isolates-Associated with Sponges Aplysina sp.}

The characteristics of the isolates that produce bioactive compounds are indicated by the formation of a clear zone around isolate. Then, isolates that have potential to produce bioactive compounds as antifungal agents were characterized morphologically through gram staining, as well as biochemical tests consisting of carbohydrate tests (glucose, sucrose, maltose and lactose), citrate tests, catalase tests, urea tests, and motility tests. 


\section{RESULT AND DISCUSSION}

\subsection{Screening of Bacteria Producing Anti-fungal}

Screening of bacteria producing antifungal compounds was carried out using Candida albicans as the target fungus. Candida albicans can live as a saprophyte (saprobe) without causing abnormalities in various organs of the human and animal bodies. Susceptible factors can cause Candida albicans to turn into a pathogen and cause a disease called candidiasis [1]. For example, oral candidiasis (thrush), vaginal candidiasis (vaginitis), systemic skin candidiasis [16].
The results from previous screening showed that 16 isolates of bacteria were isolated [14]. Four bacterial isolates could produced antifungal compounds. The results of the antifungal compound are characterized by the clear zone forming around the bacterial isolates scratches or around the disc paper (Figure 1). The bacterial isolates that produce antifungal compounds can inhibit or kill the target microbes. Microbes produce bioactive metabolites, which is believed to have a mutualistic symbiotic relationship with sponges, microbes produce metabolites that can protect sponges from disease-causing microbes [17]. The bioactive compounds produced from each isolate seen in the table below.

Table 1. The microbial activity resulted from bacterial screening associated with the sponge Aplysina sp.

\begin{tabular}{|c|c|c|c|c|c|c|}
\hline No & Test Isolate & $\begin{array}{l}\text { Isolate } \\
\text { Code }\end{array}$ & $\begin{array}{l}\text { Isolated } \\
\text { culture }\end{array}$ & Supernatant & Pellet & $\begin{array}{l}\text { Antimicrobe activity } \\
\text { (inhibition zone) }\end{array}$ \\
\hline 1 & \multirow{4}{*}{$\begin{array}{l}\text { Candida } \\
\text { albicans }\end{array}$} & APD3 & 6,1 & 7,2 & 7 & Moderate \\
\hline 2 & & APD10 & 14,9 & 14 & 14 & Strong \\
\hline 3 & & APD11 & 12,8 & 12,8 & 12,8 & Strong \\
\hline 4 & & APD15 & 14,4 & 13,2 & 13 & Strong \\
\hline
\end{tabular}

Classification zone of inhibition (ZOI) in four intensities corresponding to ZOI diameters: >20 mm, very strong; $10-20 \mathrm{~mm}$, strong; 5 $10 \mathrm{~mm}$, moderate; and $<5 \mathrm{~mm}$, no response [18].

The antagonist test of bacteria associated with the sponge Aplysina sp. against the pathogenic fungus, Candida albicans show each bacterium has a different ability to produce bioactive compounds that are characterized by differences in the size of the clear zones produced. As can be seen from the four isolates, APD10 isolate had great activity because it produced clear zones with $14.9 \mathrm{~mm}, 14 \mathrm{~mm}$, and $14 \mathrm{~mm}$. Then followed by APD15 isolates clear-zone sizes with $14.4 \mathrm{~mm}, 13 \mathrm{~mm}$, and $13.2 \mathrm{~mm}$, APD11 isolates clear-zone sizes with 12.8 $\mathrm{mm}, 12.8 \mathrm{~mm}$, and $12.8 \mathrm{~mm}$, and APD3 isolates zone size clear with $6.1 \mathrm{~mm}, 7 \mathrm{~mm}$ and $7.2 \mathrm{~mm}$.
The difference in the area of the inhibition zone of each isolate is thought to be due to the diversity of bioactive compounds possessed by each isolate as well as the resistance ability of each type of bacteria. The bioactive compounds produced are secondary metabolites as an effort for self-defense in competing with other microbes in obtaining nutrients [19]. The production of bioactive compounds is also influenced by several factors, namely nutrient supply, oxygenation, temperature, and $\mathrm{pH}$ [20].

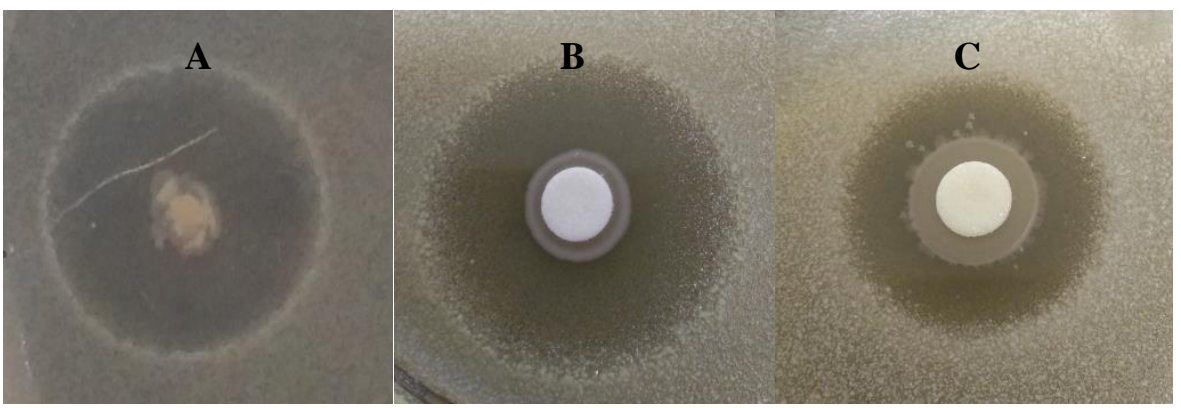

Figure 1. The clear zone produced by bacteria associated with the sponge Aplysina sp. as an antifungal; A = Clear zone from APD10 isolate culture, $\mathrm{B}=$ Clear zone from APD10 isolate pellets, and C = clear zone from APD15 supernatant. 
The formation of a clear zone around the isolates showed inhibitory activity against the growth of the tested microbes from bioactive compounds produced by bacterial isolates. From the observations, four isolates showed clear zones around their colonies, namely isolates APD3, APD10, APD11, and APD15, with different clear zone areas. According to [21], the inhibitory activity of the tested microbes can be influenced by the age of the microbes. If the microbes used are still young (stationary), it will be easier to denature the cell membrane proteins and cause the development of colony growth to be smaller. Meanwhile, microbes that are old (exponential) will be more susceptible to other compounds that can damage their cell walls. This vulnerability causes microbial growth to be unhindered.

\subsection{Identification of Potential Bacterial Isolates- Associated with Sponges Aplysina sp.}

The morphological characterization of potential bacterial isolates was carried out with two observations, with macroscopic and microscopic. Macroscopic observations were made by looking at the morphological characters and biochemical components of the colony of potential isolates and microscopic observations were made with Gram stain. Gram staining is performed to differentiate two groups of bacteria, namely Gram-positive bacteria, and Gram-negative bacteria. Gram-positive staining is indicated by a purple result, while Gramnegative bacteria show a red result. The difference in the response of bacteria to the Gram stain mechanism is based on the structure and chemical components of the bacterial cell wall. According to [22], Gram-positive bacteria have thicker cell walls with the main component consisting of peptidoglycan and having a single cell membrane. Whereas Gram-negative bacteria have a thinner cell wall consisting of two layers of membranes. The inner membrane consists of peptidoglycan while the outer membrane consists of lipopolysaccharides and lipoproteins.

The results of the Gram stain observations in Figure 2 show that four isolates have the same shape and arrangement, they have a bacillus shape with diplobacyl cell arrangement.

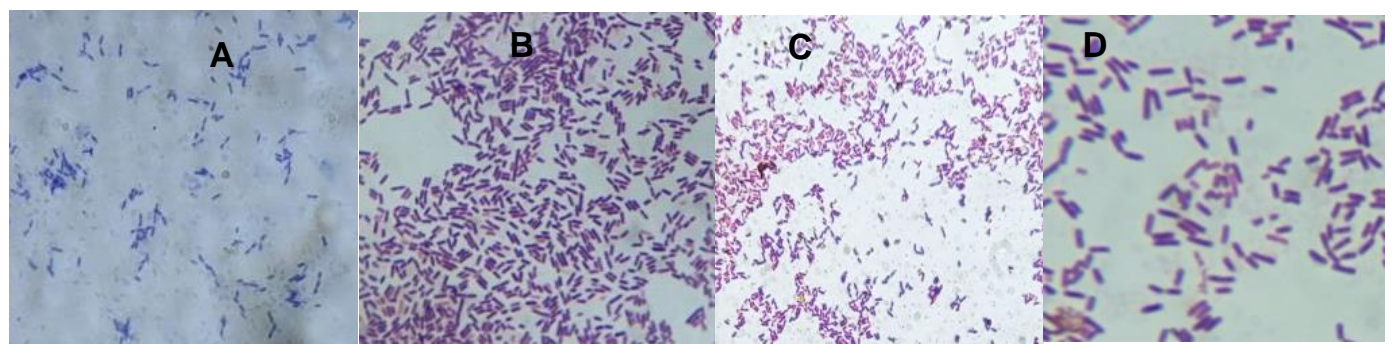

Figure 2. Gram staining used a Binocular Microscope with a magnification of 1000x on the isolates: $A=A P D 3, B=$ APD10, C = APD11 and APD15.

The results of the biochemical reaction test of bacterial isolates-associated with the sponge Aplysina sp. shown in Table 2.

Table 2. Morphological and biochemical characterization of potential isolates.

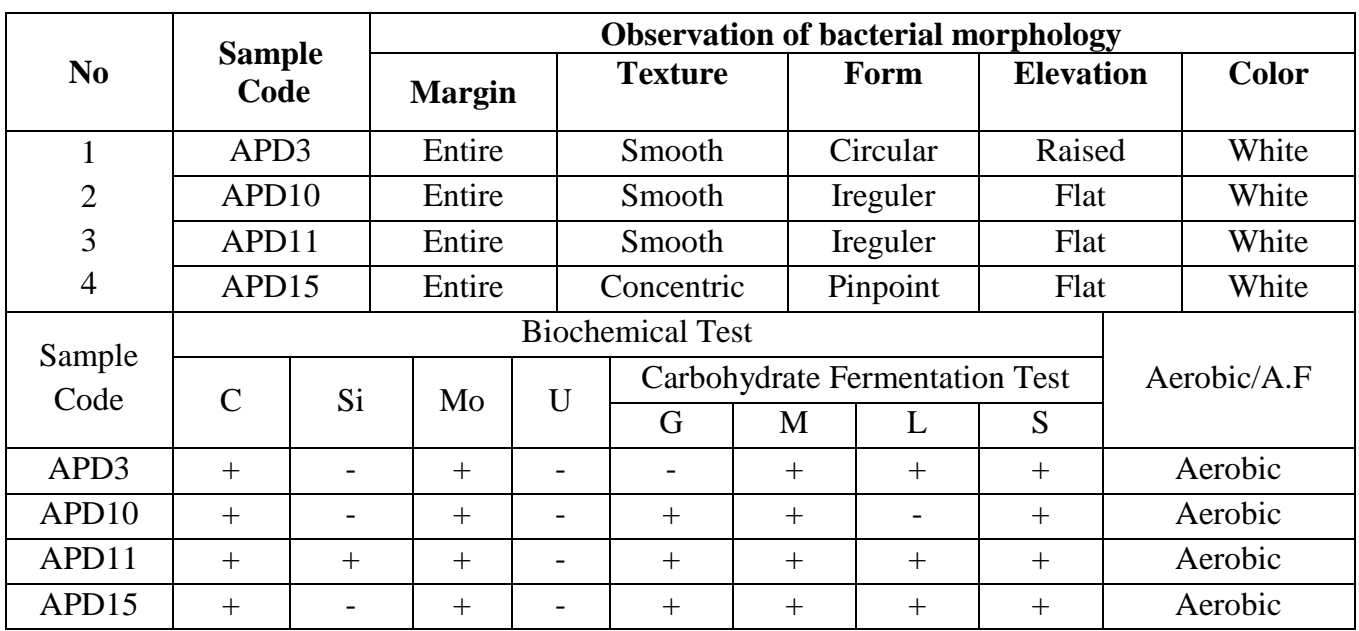

Note: $\mathrm{C}=$ Catalase test; $\mathrm{Si}=$ Citrate test; $\mathrm{Mo}=$ Motility test; $\mathrm{U}=$ Urea test; $\mathrm{G}=$ Glucose test, $\mathrm{M}=$ Maltose test, $\mathrm{L}=$ Lactose test, $\mathrm{S}=$ Sucrose test 
Based on the results of biochemical tests in Table 2 , it is evident that each bacterium has different physiological properties. This can be seen from the ability of each of these bacteria to use and decipher existing molecules. Characteristics of bacterial isolates-associated with sponge Aplysina sp, which was carried out morphologically with identification strips that had been identified using Bergey's Manual of Determinative Bacteriology (1994), showing four isolates were Bacillus, characterized by rod-shaped cells, Gram-positive stain, and positive catalase-test. According to [22], the genus Bacillus has interesting physiological properties because each type has different abilities, including (1) able to degrade organic compounds such as protein, starch, cellulose, hydrocarbons, and agar, (2) able to produce antibiotics; (3) play a role in nitrification and, denitrification; (4) nitrogen fixers; (7) is chemolithotrophic, aerobic or anaerobic, acidophilic, psychrophile, or thermophilic.

\section{CONCLUSION}

Antifungal compounds from bacteria-associated with the sponge Aplysina sp. against Candida albicans found in four isolates with the code APD3, APD10, APD11, and APD15. Of the four isolates that had inhibitory activity, namely the APD10 isolate with a strong inhibition zone diameter. Four potential isolates are closely related to the genus Bacillus.

\section{ACKNOWLEDGMENT}

The author would like to thank the Bengkulu University Research and Community Service Institute (LPPM) through 2020 Research Grant (Hibah Unggulan Fakultas MIPA) Grant number: 2049 / UN30.12 / HK / 2020 dated 09 July 2020 to Risky Hadi Wibowo. The author also thanks to the people of Enggano Island, Bengkulu Province, and all parties who have helped the completion of this research.

\section{REFERENCES}

[1] R. S. Siregar, 'Fungal Skin Disease $2^{\text {th }}$ Edition', EGC., Jakarta, 2004.

[2] T. H. Febriani, 'Antifungal Power Test of Pare (Momordicacharantia L.) Juice Against In Vitro Growth Inhibition of Candida albicans'. Publication manuscript, Faculty of Dentistry,Muhamadiyah University, 2014.

[3] U. Hentschel, K. M. Usher, and M. W. Taylor, 'Marine sponges as microbial fermenters', FEMS Microbiology Ecol, vol. 55, no. 2, pp. 167-177,
2006 doi: https://doi.org/10.1111/j.15746941.2005.00046.x

[4] I, Bhatnagar, and S. K. Kim, 'Immense Essence of Excellence: Marine Compounds', Marine Drugs, vol. 8 , no. $10, \quad$ pp. 26732701,2010,doi:10.3390/md8102673.

[5] T. R. Thomas, D. P. Kavlekar, and P. A. Loka Bharathi, 'Marine drugs from spongemicrobe association-A review', Marine Drugs, vol. 8, no. 4, pp. 1417-1468, 2010, doi: 10.3390/md8041417.

[6] M. E. Hay, 'Marine chemical ecology: chemical signals and cues structure marine populations, communities, and ecosystems', Annual Review of Marine Science, vol. 1, pp. 193- 212, 2009, doi: https://doi.org/10.1146/annurev.marine.010908.1637 08 .

[7] J. W. Blunt, B. R. Copp, R.A. Keyzers, M.H. Munro, and M. R. Prinsep, 'Marine natural products', Natural Product Report, vol. 3 no. 3, pp. 382-431, 2016, doi: 10.1039/c5np00156k.

[8] S. P. Banakar, L. Karthik, and Z. Li, 'Mass production of natural products from microbes derived from sponges and corals, In: Symbiotic Microbiomes of Coral Reefs Sponges and Corals', Springer, Dordrecht, pp. 505-526. 2019.

[9] L. Pita, L. Rix, B. M. Slaby, A. Franke, and U. Hentschel, 'The sponge holobiont in a changing ocean: from microbes to ecosystems', Microbiome, no. 6 , pp. 46, 2018, doi: /10.1186/s40168-018-04281 .

[10] A. Indraningrat, H. Smidt, and D. Sipkema, 'Bioprospecting Sponge-Associated Microbes for Antimicrobial Compounds', Marine Drugs, vol. 14, no. 5, pp. 87, 2016, doi: 10.3390/md14050087.

[11] I. B. Subagio, and Aunurohim, Sea Sponge Community Structure (Porifera) at Pasir Putih Beach, Situbondo, Jurnal Sains Dan Seni Pomits, vol. 2 no. 2, pp. 2337-3520, 2013, (in Bahasa). doi: $10.12962 / \mathrm{j} 23373520 . v 2 \mathrm{i} 2.3962$

[12] M. W. Taylor, R. Radax, D. Steger, and M. Wagner, 'Sponge Associated Microorganisms: Evolution, Ecology, and Biotechnological Potential, Microbiology and Molecular Biology Reviews, vol. 71 , no. 2, pp. 295, 2007, doi: 10.1128/MMBR.00040-06

[13] U. Hentschel, J. Piel, S. M, Degnan, and M. W. Taylor, 'Genomic insights into the marine sponge microbiome', Nature Reviews Microbiology, vol. 10, pp. 641-645, 2012, doi: 10.1038/nrmicro2839.

[14] R. H. Wibowo, Sipriyadi, D. Welly, P. P, Hizkia, and R. Pertiwi, 'Potential Of Isolates Bacillus Sp. Eng-4 Associated With Aplysina sp. Sea Sponge As 
Producing Antimicrob Compounds From Enggano Island,' Jurnal Enggano, vol. 5, no. 1, pp. 1 - 10, 2020. doi: https://doi.org/10.31186/jenggano.5.1.110. (in Bahasa).

[15] H. Abubakar, A. T. Wahyudi, and M. Yuhana, 'Screening of Bacteria Associated with Sponge Jaspis sp as a Producer of Antimicrobial Compounds', Marine Science, vol. 16, no. 1, pp. 35 40 , 2011 , doi: https://doi.org/10.14710/ik.ijms.16.1.35-40.

[16] C. R. Tjampakasari, 'Characteristics of Candida albicans', World Mirror Journal of Medicine, no. 151, pp. 33-36, 2010.

[17] J. Kennedy, P. Baker, C. Piper, P. D. Cotter, M. Waish, M. J. Mooij, M. B. Bourke, M. C. Rea, P. M. O'Connor, R. P. Ross, C. Hill, F. O'Gara, J. R. Marchesi, and Dobson A. D. W, 'Isolation and analysis of bacteria with antimicrobial activities from the marine sponge Haliclona simulans collected from Irish Waters', Marine Biotechnology, vol.11, pp. 384-396. 2009, doi: 10.1007/s10126-008-9154-1.

[18] W. W. David, and T. R. Stout, 'Disc plate method of microbiological antibiotic assay. I. Factors influencing variability and error', Applied Microbiology, no. 22, pp. 659-665, 1971.
[19] E. M, Miguelez, C. Hardisson, and M. B. Manzanal, 'Streptomyces: a new model to study cell death', International Microbiology. vol. 3, pp. 153-158, 2000.

[20] C. Olano, F. Lombo, C. Mendez, J. A. Salas, 'Improving production of bioactive secondary metabolites in actinomycetes by metabolic engineering', Metabolic Engineering, vol. 10, pp. 281-285, 2008,doi: 10.1016/j.ymben.2008.07.001

[21] Z. Octarya, and R. Saputra, The Effect of Type of Solvent on the Amount of Extract and Antifungal Power of Chinese Ketepeng (Cassia alata) Leaves against Trichophyton sp., Jurnal Photon, vol. 5, no. $2,2015$.

[22] K. Irianto, Microbiology Reveals World of Microorganisms, CV. Yrama Widya, Bandung, 2006. (in Bahasa).

[23] D. Claus, and R. C. W. Berkeley, 'Genus Bacillus, In : Bergeys Manual of Systematic Bacteriology', vol. 2 (SNEATH, P.H.A., ed.), Williams and Wilkins, Baltimore, pp. 1105-1139, 1986. 